\title{
Improvements in Hazelnuts in the United States
}

\author{
Jeff Olsen ${ }^{1}$ \\ Oregon State University Extension Service, 2050 Lafayette Avenue, McMinnville, OR 97128
}

Additional index words. Corylus avellana, flowering, production, orchard management, filbert, alleles, eastern filbert blight, germplasm

\begin{abstract}
In the mid-1980s, eastern filbert blight (EFB) fungus, Anisogramma anomala (Peck) E. Müller, was discovered in Oregon's main hazelnut-producing region and now is present throughout the hazelnut-producing area. Oregon State University's (OSU) Hazelnut Breeding Program responded by developing EFB-resistant cultivars, the first of which was released in 2005. The breeding program has also selected for other beneficial traits such as uniform early nut maturation, larger kernel size, and improved kernel quality. A 2008 OSU economic study on the costs of establishing and producing hazelnuts showed that the EFB-resistant cultivars enhanced economic viability of orchards, increasing cumulative cash flow during the 12-year establishment period by \$12,243 per hectare. Several completely resistant cultivars have been released from the OSU Hazelnut Breeding program, all of which have 'Gasaway' as a resistance source, which transmits a dominant allele at a single locus that provides resistance to EFB. Additional EFB-resistant genotypes have also been identified from a diversity of origins that are being integrated into the OSU breeding program to produce new cultivars expressing multiple sources of genetic resistance. Interest in growing hazelnuts is increasing in other parts of the United States; for example, the Arbor Day Foundation began the Hazelnut Research Project in 1996 in Nebraska. A Hybrid Hazelnut Consortium was formed to join the leading hazelnut researchers in the United States. The Consortium's goal is to create a world-leading research and breeding program to develop hazelnuts as a widely adapted, high-yielding, and low-input sustainable crop that is competitive with annual crops for food, feed, or bioenergy. At Rutgers University, there has been a program of breeding and research for hazelnuts for the eastern United States since 1996. The program currently has $\approx 11,000$ hazelnut seedlings undergoing evaluation. The Rutgers program is also looking for winter-hardy genotypes. They have been working closely with OSU to assess the response of OSU hazelnut selections that are resistant to EFB in Oregon when they are exposed to EFB isolates collected from across the eastern United States. This work has demonstrated the need for cultivars to express multiple sources of resistance and has prompted quarantine on importation of hazelnut plants into Oregon from other states where EFB strains may differ. Rutgers is also searching for new sources of resistance to EFB from seedling populations from Europe with the goal of integrating these sources into American germplasm. More effective Integrated Pest Management for EFB-susceptible hazelnut cultivars has been developed by OSU scientists. They recommend a management program that integrates scouting for and pruning infected tissue, fungicidal sprays, and the use of more resistant cultivars. Advances in hazelnut fertilizer management have included descriptions of patterns of nitrogen uptake, distribution, and use using isotopically labeled nitrogen.
\end{abstract}

Corylus avellana (L.) or European hazelnut is a member of the birch (Betulaceae) family. It has a unique floral biology with bloom occurring in the winter, although fertilization of the ovule, and subsequent nut set, is not complete until in mid-May (Thompson, 1979). In Oregon, nut harvest starts in the fall when the nuts fall from the tree and are picked up with mechanical harvesters.

Total world production of hazelnuts in 2008 was $1,066,823 \mathrm{t}$ and $773,828 \mathrm{t}$ in 2009 with Turkey accounting for $\approx 70 \%$ of the total in both years. Italy produces $\approx 14 \%$, whereas Oregon accounts for $3 \%$ to $5 \%$ of annual world production (Food and Agriculture Organization of the United Nations, 2010). Oregon's Willamette Valley produces $\approx 99 \%$ of the U.S. hazelnut crop. Growers in Oregon in 2009 produced $\approx 37,188 \mathrm{t}$ of hazelnuts on 12,545 ha. In the mid-1980s, EFB, caused by the fungus Anisogramma anomala (Peck) E. Müller, was discovered in Oregon's main hazelnut-producing region. The blight has slowly spread and is now present throughout the entire hazelnut-producing area in Oregon.

Received for publication 25 Aug. 2010. Accepted for publication 28 Dec. 2010.

This paper was part of the workshop "Advances in Specialty Nut Crops" held 25 July 2009 at the ASHS Conference, St. Louis, MO, and sponsored by the Temperate Tree Nut Crops (NUTS) Working Group. ${ }^{1}$ Oregon State University Extension Horticulturist. e-mail jeff.olsen@oregonstate.edu.

\section{GERMPLASM IMPROVEMENT}

Oregon State University's Hazelnut Breeding Program run by Dr. Shawn Mehlenbacher responded to the threat of EFB by developing EFB-resistant cultivars. The breeding program has also selected for other traits beneficial to commercial production such as uniformly early nut maturation, larger kernel size expressed as a percentage of the whole nut weight, and improved kernel quality. The following completely resistant cultivars have been released from the OSU Hazelnut Breeding Program: 'Santiam' (OSU 509.064) in 2005 (Mehlenbacher et al., 2007), 'Yamhill' (OSU 542.102 ) in 2008 (Mehlenbacher et al., 2009), and 'Jefferson' (OSU 703.007) in 2009 (Mehlenbacher, 2009). Two late-shedding pollenizers for 'Jefferson' were released, 'Eta' and 'Theta' in 2009 (Mehlenbacher, 2009). All of these releases have 'Gasaway' as a source of single-gene resistance to EFB.

'Santiam' (OSU 509.064) has a similar yield as 'Barcelona', but the tree size is $75 \%$ that of 'Barcelona', resulting in a higher yield efficiency ( $170 \%$ of 'Barcelona'). 'Santiam' has a higher percent kernel ( $48 \%$ to $52 \%$ compared with 'Barcelona' at $43 \%$ kernel). Its harvest time is 10 to $15 \mathrm{~d}$ before 'Barcelona'.

'Yamhill' (OSU 542.102) has a tree size that is $50 \%$ that of 'Barcelona', which gives it very high yield efficiency ( $220 \%$ of 'Barcelona'). 'Yamhill' has 49\% kernel weight and is harvested $14 \mathrm{~d}$ before 'Barcelona' (Mehlenbacher, 2009).

'Jefferson' (OSU 703.007) represents a replacement for 'Barcelona', the industry stan- dard for the in-shell market. 'Jefferson' is $\approx 65 \%$ the tree size as 'Barcelona' with a similar upright growth pattern. 'Jefferson' had higher cumulative nut yields per tree than 'Barcelona' and thus had higher nut yield efficiency per tree (162\%). Nuts of 'Jefferson' are large (3.2 to $4.2 \mathrm{~g}$ ) and similar in size to 'Barcelona' (3.8 g) and have a slightly higher percent kernel ( $45 \%$ versus $43 \%$ ). 'Jefferson' harvest is with 'Barcelona' or up to $3 \mathrm{~d}$ later.

An OSU economic study on the costs of establishing and producing hazelnuts was completed in 2008. It showed that the EFBresistant cultivars available to Oregon hazelnut producers can enhance economic viability of the orchard by increasing the cumulative cash flow over the course of the 12-year establishment period by $\$ 12,243$ per hectare compared with standard susceptible cultivars requiring scouting, pruning, and four fungicides sprays each spring (Julian et al., 2009).

A worldwide genetic resource collection has been made over the course of the last 24 years with complete resistance to EFB in Corylus avellana (L.) discovered in the following genotypes: 'Gasaway' from Washington, 'Zimmerman' from Oregon, 'Weschcke Seedling' (OSU 08.040) from Minnesota, 'Ratoli' from Spain, Georgian 759.010 from the Republic of Georgia, OSU 495.072 from Russia, COR 157 from Finland, 'Uebov' from Cacak, Serbia, 'Crvejne 3/96' from Cacak, Serbia, 'Culpla' from Spain and Moscow N01, N02 from Moscow, Russia (Vidyasagar et al., 2010). These genotypes are being integrated into the OSU Hazelnut Breeding Program to produce new cultivars expressing a wide diversity of 
genes for resistance to EFB (Honglin et al., 2007).

The Arbor Day Foundation began a Hazelnut Research Project in 1996 with the planting of 3.6 ha of hybrid hazelnuts at Arbor Day Farm in Nebraska. Their plants came from hybrid hazelnuts from Badgersett Research Farm in Minnesota and combined mostly the American hazelnut, Corylus americana (Walter), and the beaked hazelnut, Corylus cornuta (Marsh.), bred through open cross-pollination.

Recently, to maximize progress, a Hybrid Hazelnut Consortium was formed to join the leading hazelnut researchers in the United States at OSU, the Arbor Day Foundation, Rutgers University, and the University of Nebraska, Lincoln. The goal of the Hybrid Hazelnut Consortium is to create a worldleading research and breeding program to develop hazelnuts as a widely adapted, highyielding, and low-input sustainable crop that is competitive with annual crops for food, feed, or bioenergy.

Dr. Thomas Molnar has been researching hazelnuts for the eastern United States since 1996 at Rutgers University. The program at Rutgers University has $\approx 11,000$ hazelnut seedlings in the field or greenhouse undergoing evaluation. In addition to assessing genotypes for their EFB response, the Rutgers program is also looking for genotypes that are winterhardy. Dr. Molnar has been working closely with Dr. Shawn Mehlenbacher of OSU to assess the response of OSU hazelnut selections that are resistant to EFB in Oregon when exposed to strains of the disease that occur in the eastern United States (Molnar et al., 2010). Dr. Molnar's team has planted $\approx 4000$ seedlings from OSU controlled crosses at Rutgers. Some of the resistant genotypes from Oregon have shown symptoms of EFB when planted on the east coast of the United States. This has demonstrated the need for building multiple sources of resistance into cultivars for the future. It has also prompted quarantine on importation of hazelnut plants into Oregon from other parts of the United States to avoid introduction of different strains of EFB into the main hazelnut-growing region of the United States. Dr. Molnar is also searching for new sources of resistance to EFB from seedling populations from Estonia, Latvia, Lithuania, Uzbekistan, Poland, Ukraine, Russia, and Kyrgyzstan and integrating them into advanced selections.

\section{PROGRESS IN HAZELNUT PRODUCTION METHODS}

More effective integrated management programs for hazelnut cultivars that are susceptible to EFB infections have been developed by OSU scientists (Johnson et al., 1996). OSU recommends a management program that integrates scouting for and pruning infected tissue, fungicidal sprays in the spring, and the use of EFB-resistant cultivars.

Advances in hazelnut fertilizer management have included discovery of nitrogen uptake, distribution, and use patterns through work with isotopically labeled nitrogen in Oregon (Olsen et al., 2000). The hazelnut tree relies on stored nitrogen reserves to fuel the growth in spring. The optimum efficiency of uptake of ground-applied nitrogen is coincident with the onset of active growth of the tree in the spring. This finding supported a more efficient application timing of nitrogen for Oregon's hazelnut industry in moving from a winter application to the spring. More recent research on hybrid hazelnuts in Minnesota found a similar result for efficiency of uptake, but the calendar year timing of the most efficient application was early summer rather than the onset of spring like in Oregon (Braun et al., 2009).

\section{SUMMARY}

The advancements in genetic improvements in hazelnut disease resistance and productivity have set the stage for a revitalization of the U.S. hazelnut industry. Cooperative efforts among the Hazelnut Consortium partners will increase the range of adaptability of the hazelnut. Continuing refinements in man- agement practices contribute to the efficiency of production in the hazelnut industry.

\section{Literature Cited}

Braun, L.C., J.H. Gillman, and M.P. Russelle. 2009. Fertilizer nitrogen timing and uptake efficiency of hybrid hazelnuts in the Upper Midwest, USA. HortScience 44:1688-1693.

Food and Agriculture Organization of the United Nations. 2010. (FAOSTAT). 8 Sept. 2010. <http:// faostat.fao.org/site/567/DesktopDefault.aspx? PageID $=567$ \#ancor $>$.

Honglin, C., S.A. Mehlenbacher, and D.C. Smith. 2007. Hazelnut accessions provide new sources of resistance to eastern filbert blight. HortScience 42:466-469.

Johnson, K.B., S.A. Mehlenbacher, J.K. Stone, J.W. Pscheidt, and J.N. Pinkerton. 1996. Eastern filbert blight of hazelnut: It's becoming a manageable disease. Plant Dis. 80:1308-1316.

Julian, J., C.F. Seavert, and J.L. Olsen. 2009. An economic evaluation of the impact of Eastern filbert blight resistant hazelnut cultivars in Oregon, USA. Acta Hort. 845:725-732.

Mehlenbacher, S.A. 2009. Release of 'Jefferson' hazelnut (OSU 703.007) and pollinizers 'Eta and 'Theta'. Proc. of the Nut Growers Society of Oregon, Washington and British Columbia. p. 57-63.

Mehlenbacher, S.A., A.N. Azarenko, D.C. Smith, and R.L. McCluskey. 2007. 'Santiam' hazelnut. HortScience 42:715-717.

Mehlenbacher, S.A., A.N. Azarenko, D.C. Smith, and R.L. McCluskey. 2009. 'Yamhill' hazelnut. HortScience 44:845-847.

Molnar, T.J., J.C. Goffreda, and C.R. Funk. 2010. Survey of Corylus resistance to Anisogramma anomala from different geographic locations. HortScience 45:832-836.

Olsen, J., T.L. Righetti, and E.I. Sanchez. 2000. Absorption and distribution of isotopically labeled nitrogen in the hazelnut tree following ground and foliar applications. Acta Hort. 556: 437-444.

Thompson, M.M. 1979. Growth and development of the pistillate flower and nut in 'Barcelona' filbert. J. Amer. Soc. Hort. Sci. 104:427-432.

Vidyasagar, R.S., S.A. Mehlenbacher, and D.C. Smith. 2010. Response of hazelnut accessions to greenhouse inoculation with Anisogramma anomala (Peck) E. Müller. HortScience 45: 1116-1119. 